\title{
BIOMETRY IN THE THIRD TRIMESTER
}

\section{R. Terinde}

Sonar has become a potential aid to sölve two problems:

1. estimating the size of the fetus "in situ"

2. judging wether this size does or does not correlate to patients menstrual history.

This can give rise to two possibilities:

Wether the fetus has developed normaly but the dates of menstrual history are wrong or wether the dates are true but the development of the fetus is abnormal for its age.

A solution to this problem is essential from the clinical point of view. Babies, being too small or too large for their gestational age are consequently suffering from an increased perinatal morbidity and mortality. To find out wether fetal development is normal it is necessary to define the normal growth curves. Measuring the fetal head the biparietal diameter is one of the most common parameters. We normaly use CAMPBELL's method introduced in 1968. Using the A-scan the markers have to beiplaced on the rising parts of both skull-echo pulse. In addition a clear midline echo must be visible. The right position of this markers have to be controlled in. B-scan. If no A-scan is avaiable as it is usable in most real-timescamners it is essential that the outlines are sharp and clearly defined. It is important to repeat the measurement until the largest biparietal diameter is found provided of course that a midline echo is always visible. To find out the nomal growth curves of the fetal trunk we used since 1974 HANSMANN's method to measure the fetal thorax. The reference plane is defined by the umbilical vein in the anterior part of the transverse scan of the fetal trumk. This reference plane enables us to measure the transverse and sagittal diameter and the abdomen circumference. Further investigations demonstrated that mean curves of the b.p.d. correlate closely to fetal age in the second trimester but not as well to fetal growth and size in the third trimester. Many authors proved that measurements of the fetal trumk improve the accuracy of birth weight predictions.

As the conditions af measuring a parameter where identical to those of HANSMANN and our machines are similar, then the mean growth curves should also be identical. Establishing normal growth curves two conditions where different from those of HANSMANN's:

1. Pregnancies of diabetic mothers or small for date babies are included in our results.

2. In prospective diagnosis using the dates of HANSMANN pregnancies with obviously wrong duration in relation to true mentrual age as given by the mother were excluded.

Looking at figure 1 showing the growth curve of the b.p.d. of our normal group and those of HANSMANN (in the background), there is a good correlation up to. the 35th week of gestation, then the growth rate in our group seems to be lower. Excluding pregnancies with miscalculated fetal age reduces the standard deviation. Our growth curve of transverse trumk diameter correlates almost perfectly to HANMANNS's curve. In figure 2 our second order polynominal has been fitted to HANSMANN's mean values and their single standard devidation. It can be clearly seen that the standard deviation is greater than for our group. In conclusion one can say, it is not necessary to establish your own normal growth curves. It is quite satisfactory to use those already established by other authors and to use their methods. 


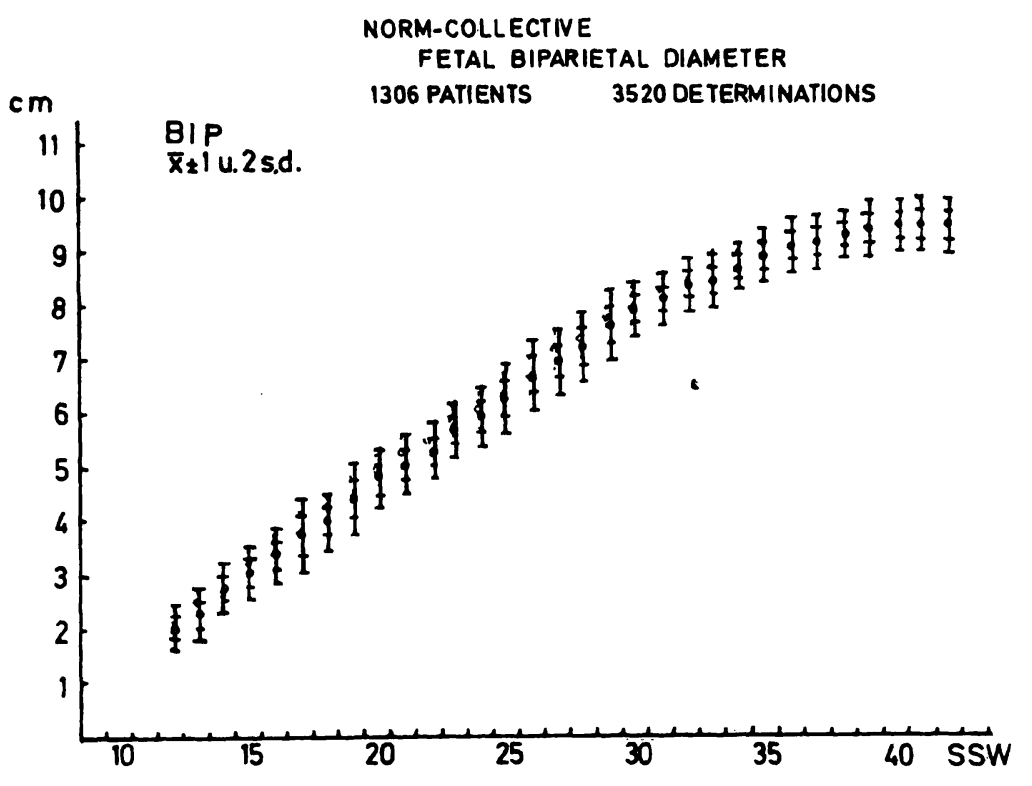

Fig. 1: B.p.d-growth curve by HANSMANN (single s. d.) and our growth curve (single and double s. d.) in comparison.

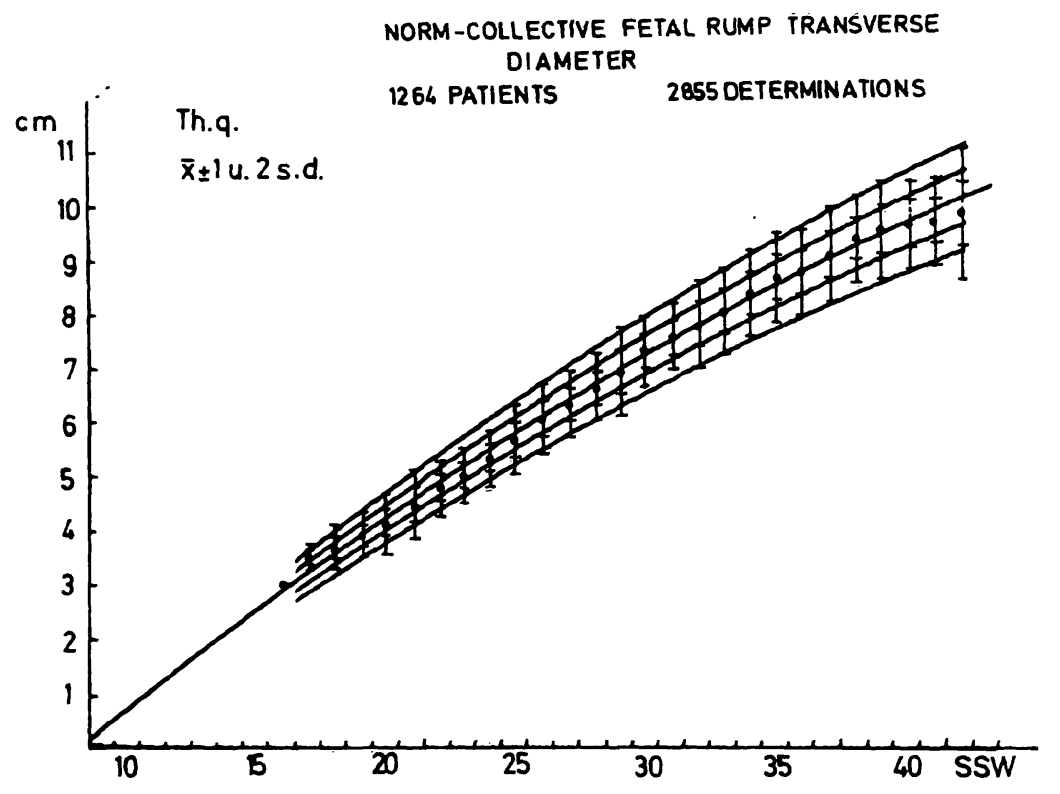

Fig. 2: Growth curve of thorax transverse by HANSMANN (single s. d.) fitted into our $2^{\text {nd }}$ degree polynomia.

As the transverse trunk diameter is the most reliable parameter of indicating fetal size we proposed that a fetus was "small for gestational age" when its actual diameter remained two weeks behind the menstrual age. A correct prognosis was made in 10 out of 60 patients (figure 3). In 7 cases a correct prognosis was made when the birth weight in "small for date" and inmature babies was below the 95th percentile of the growth curve as established by v.HARNACK. 23 babies showed a birth weight between 2500 and $3000 \mathrm{~g}$. In my opinion this borderline group should not be seen as a disadvantage of this screening method. In 10 patients the last determination was too far away from the date of delivery. Ultrasound was totaly wrong in $12 \%$. In those babies which are tó large for gestational age we diagnosed macrosomia when the biparietal diameter was in the range of mentrual age, but the transverse trunk diameter was two weeks above compaired to mean values. Looking at figure 4, we can notice that screening for a big baby in this way is less succesful than screening for a "small for date baby". In 37 : the prognosis was correct but a fault of ultrasound was made in $25:$ 
PROSPECTIVE DIAGNOSIS OF S.F.D.-BABIES BY

THORACOMETRY 101 DETERMINATIONS IN 60 PATIENTS

\begin{tabular}{|c|c|c|}
\hline & $\begin{array}{l}\text { No. } \\
\text { OF PATIENTS }\end{array}$ & PERCENTAGE \\
\hline RIGHT PROGNOSIS, S.F.D. -BABY & 10 & 16,6 \\
\hline $\begin{array}{l}\text { RIGHT PROGNOSIS, S.F.D.-BABY } \\
\text { BELOW } 2500 \text { G AND IMMATURE }\end{array}$ & 7 & 11,7 \\
\hline $\begin{array}{l}\text { GOOD PROGNOSIS, BIRTH WEIGHT } \\
\text { BETWEEN } 2500 \text { AND } 3000 \text { G }\end{array}$ & 23 & 38,3 \\
\hline $\begin{array}{l}\text { LAST DETERMINATION MORE THAN } \\
28 \text { DAYS BEFORE DELIVERY }\end{array}$ & 10 & 16,7 \\
\hline $\begin{array}{l}\text { FAULT, BUT LAST DETERMINATION } \\
\text { MORE THAN 14. BEFORE DELIVERY }\end{array}$ & 4 & 6,7 \\
\hline FAULT BY ULTRASOUND & 7 & 11,7 \\
\hline
\end{tabular}

Fig 3: Results of prospective sreening for a small for date baby by Thoracometry.

PROSPECTIVE DIAGNOSIS OF BIG BABIES BY THORACOMETRY 130 DETERMINATIONS IN 63 PATIENTS

\begin{tabular}{|c|c|c|}
\hline & $\begin{array}{l}\text { No. } \\
\text { OF PATIENTS }\end{array}$ & PERCENTAGE \\
\hline $\begin{array}{l}\text { MACROSOMATIA, BIRTH WEIGHT ABOVE } \\
4000 \mathrm{G} \text {, MATURE }\end{array}$ & 6 & 9,5 \\
\hline MACROSOMATIA AND PREMATURITY & 7 & 11,1 \\
\hline $\begin{array}{l}\text { MACROSOMATIA, LAST DETERM, MORE } \\
\text { THAN } 7 \text { DAYS BEFORE DELIVERY }\end{array}$ & 11 & 17,5 \\
\hline $\begin{array}{l}\text { GOOD ESTIMATION, BIRTH WEIGHT } \\
\text { BETWEEN } 3800 \text { AND } 4000 \mathrm{G}\end{array}$ & 9 & 14,2 \\
\hline $\begin{array}{l}\text { LAST DETERMINATION MORE THAN } \\
14 \text { DAYS BEVORE DELIVERY }\end{array}$ & 14 & 22,2 \\
\hline FAULT BY ULTRASOUND & 16 & 25,4 \\
\hline
\end{tabular}

Fig 4: Results of prospective screening for a "big baby" by Thoracometry.

\author{
Dr.R.Terinde \\ Univ.-Frauenklinik \\ Moorenstr. 5 \\ D-4000 Düsseldorf $1 /$ Germany
}

